Original Research Paper

\title{
Physiological and Molecular-Genetic Evaluation of Rice Breeding Resources on Cold Tolerance for Creating New Varieties for the Northern Zone of Rice Cultivation
}

\author{
${ }^{1}$ Yeldos Almabekovich Zhanbyrbayev, ${ }^{2}$ Aiman Bokenovna Rysbekova, \\ ${ }^{3}$ Bakdaulet Naubaevich Usenbekov, ${ }^{4}$ Dauren Tabiyltaevish Kazkeyev, \\ ${ }^{5}$ Batyrbek Ashirimbetovich Sarsenbayev and ${ }^{6}$ Grigoriy Leonidovich Zelensky \\ ${ }^{1}$ Institute of Biology and Plant Biotechnology, Timiryazev St. 45, Almaty, 050040, \\ Kazakh National Agrarian University, Abay Av 8, Almaty, 050010, Republic of Kazakhstan, \\ ${ }^{2}$ Institute of Biology and Plant Biotechnology, Timiryazev St. 45, Almaty, 050040, \\ S. Seifullin Kazakh Agrotechnical University, Pobedy Av. 62, Astana, 010000, Kazakhstan \\ ${ }^{3,5}$ Institute of Biology and Plant Biotechnology, Timiryazev St. 45, Almaty, 050040, Republic of Kazakhstan \\ ${ }^{4}$ Kazakh National Agrarian University, Abay Av 8, Almaty, 050010, Republic of Kazakhstan \\ ${ }^{6}$ All-Russian Rice Research Institute, Belozerny 3, Krasnodar, 350921, Russia
}

Article history

Received: 11-07-2017

Revised: 08-08-2017

Accepted: 16-09-2017

Corresponding Author:

Yeldos Almabekovich

Zhanbyrbayev

Kazakh National Agrarian

University, Abay Av 8, Almaty,

050010, Republic of

Kazakhstan, Institute of

Biology and Plant

Biotechnology, Timiryazev St.

45, Almaty, 050040, Republic

of Kazakhstan

Email: eldos_83@mail.ru

\begin{abstract}
This study was aimed at assessing cold tolerance of rice breeding materials produced in Kazakhstan and foreign countries in the phase of seed germination, creating initial cold-tolerant forms and lines to derive Kazakhstan varieties of rice and identifying in the selection material the genes of the quantitative loci of cold tolerance (qPSST-3, qPSST-7 and qPSST-9), based on the molecular-genetic approach. 29 rice varieties were screened in the laboratory condition for cold tolerance and cold sensitivity when exposed to cold stress. By the results of screening in the early phase of rice growth, the most cold-tolerant varieties were chosen, such as Kuban 3, UzROS 7-13 and Lazurny. The chosen promising varieties were used as the female parent form for creating coldtolerant hybrids. Microsatellite DNA profiles were obtained for rice varieties of Kazakh, Russian breeding and breeding of other countries by the loci that are closely related to the Quantitative Loci (QTLs) of cold tolerance. Screening tests of IPBB rice genetic plasma for cold tolerance helped to identify donors of useful agronomic traits, which are extremely important for developing promising pre-selection resources.
\end{abstract}

Keywords: Rice, Cold Tolerance, Germinating Power, Hybridization, Quantitative Loci of Cold Tolerance

\section{Introduction}

The Republic of Kazakhstan refers to the northernmost area of rice cultivation in the world. Rice fields are found up to $44^{\circ} 51^{\prime}$ of North latitude (zone I). By the natural features, the area of rice cultivation may be divided into three climatic zones:

- I Northern-the Karatal, the Akdalin, the Tasmurun, the Charyn, the Kazalin massifs. The sum of temperatures $\left(2,700-3,250^{\circ} \mathrm{C}\right)$ over the rice vegetation period with the temperatures above $+15^{\circ} \mathrm{C}$
- II Central-Kyzylorda, Shiely. The sum of temperatures $\left(3,250-3,600^{\circ} \mathrm{C}\right)$ over the rice vegetation period with the temperatures above $+15^{\circ} \mathrm{C}$

- III South-Togusken, Kyzylkum with the total temperature over $3,600^{\circ} \mathrm{C}$

The boundaries of the zones are made by the isolines of average amounts of temperatures over $+15^{\circ} \mathrm{C}: 3,100,3,300$ and $3,500^{\circ} \mathrm{C}$, which characterize the optimum conditions for complete annual ripening of early ripening, mid-season ripening and late ripening varieties of rice. 
The total area of engineering systems for rice cultivation in view of crops rotation in rice crop rotation is about 225 thousand ha. According to statistics, every year Kazakhstan produces 280 to 350 thousand tons of paddy rice. In the main region of rice cultivation in the Republic, the Kyzylorda region, $90 \%$ of rice crops in Kazakhstan are located.

Unstable seasonal atmospheric pressure in various years results in sharp changes in the climatic conditions. Therefore, in the Republic of Kazakhstan, the task of creating varieties tolerant to cold stress in the initial period of growth and development of rice plants with high germination force in the field and increased growth energy against the unfavorable temperature conditions is very urgent (Kovalenko and Dudenko, 1974).

Low temperatures result in a number of undesirable consequences: They reduce the germinating energy of seeds and their photosynthetic activity, causing leaf discoloration, reduce plant height and productivity of spikelets per panicle, cause degeneration of spikelets per panicle, cause delay of its emergence and uneven ripening of grains and low grain quality. The effect of low temperatures is manifested at various stages of rice plant growth (Suh et al., 2010). In this regard, in the programs of breeding rice tolerant to cold stress, the first and the most important stage is initial screening of selection samples to identify donors of tolerance to this stress factor. It has been found that cold tolerance of rice is a complex polygenic trait and is due to simultaneous disruption of several physiological and biochemical mechanisms that affect various metabolic processes (Kostylev et al., 2004). It is known that genotypes of rice of subspecies japonica are more tolerant to low temperature and feature cold tolerance, compared to those of subspecies indica. Quantitative characteristic of rice cold tolerance at the stage of seedlings is controlled by two genes $C t s-1, C t s-2(\mathrm{t})$; in the booting phase-by several genes. Although the genetic mechanisms of rice cold tolerance at this stage of ontogenesis have not been studied enough, some of them were successfully identified with the use of the QTL analysis. For example, in their work, Saito et al. (2004) were identified two closely related quantitative loci $(C t b-1$ and $C t b-2)$ of cold tolerance associated with the length of the anther. Takeuchi et al. (2001) have built a linkage map with the help of RFLP and RAPD molecular markers and found the total of eight quantitative loci of cold tolerance. The QTL-analysis performed by another research group allowed to identify other three QTL-loci (qPSST-3, qPSST-7 and qPSST-9), the total contribution of which into the phenotypic variation by this trait was $27.4 \%$. In addition, the authors identified SSR markers RM569, RM1377, RM24545, which were closely related to these loci. The phenotypic test for cold tolerance was the calculation of the percentage of germinated seeds in the irrigation water at $18-19^{\circ} \mathrm{C}$ and at the controlled temperature $\left(17^{\circ} \mathrm{C}\right)$ in a greenhouse (Suh et al., 2010).

This study was aimed at assessing cold tolerance of rice breeding samples in the germination phase for creating initial cold-tolerant forms and lines and identification of quantitative loci of cold tolerance (qPSST-3, qPSST-7 and qPSST-9), based on the molecular-genetic approach.

\section{Methods}

\section{Assessing Cold Tolerance}

According to the data of the Scientific Rice Research Institute, the varietal differences in the rice seeds germination rates are most evident at low temperature of $14^{\circ} \mathrm{C}$ and become less evident at lower and higher temperatures. 75 seed samples were immersed in $12 \%$ $\mathrm{N}_{2} \mathrm{O}_{2}$ for $15 \mathrm{~min}$ to destroy harmful micro flora on the grains, after which they were rinsed 2 times with distilled water. Treated seeds were immersed for $2 \mathrm{~h}$ in water at the room temperature to accelerate swelling. Then the seeds were placed in a Petri dish with moistened (two layers) filter paper with 3 repetitions, 25 grains in each and placed into a climatic chamber at the constant temperature of $14^{\circ} \mathrm{C}$, the photoperiod of $16 \mathrm{~h} /$ day and $8 \mathrm{~h} /$ night and the illuminance of 2,000 Lux. The reference plants were grown at the temperature of $28^{\circ} \mathrm{C}$. Germination of part of the grains was observed on the 2-nd day in the reference group, on the 5-th day in the experiment; the number of grains was counted. The following calculations were made every day. The counting was finished on the 13th day of the experiment and the germination energy of rice seeds was determined. Simultaneously with the germination energy, the germination ability of seeds in the reference and experimental samples was calculated (Skazhenik et al., 2009).

\section{Hybridization}

Hybridization of rice varieties was performed with the use of the pneumatic sterilization method and the "Twell" method of pollination (Los, 2007).

\section{DNA Extraction and the PCR Profile}

DNA was extracted from plant samples with the use of achlorophyllous 7-day seedlings obtained by incubation in a humid chamber: In a sterile Petri dish, on moist sterile filter paper, in the dark, at the temperature of $25^{\circ} \mathrm{C}$. DNA was extracted with the use of the CTAB method (Murray and Thompson, 1980). In all experiments of this study, all used primers were synthesized by the Applied Biosystems company (USA). 
PCR was performed with the DNA concentration of 40-50 ng in the final volume of $10 \mu \mathrm{L}$. Reaction mixture $2 \times$ Green Master Mix (USA) was used. DNA amplification was performed on amplifier T100 Thermal Cycler, Bio-Rad (USA) in the following conditions: Initial DNA denaturation-4 $\mathrm{min}$. at $95^{\circ} \mathrm{C}$, following 35 cycles: Denaturation $30 \mathrm{sec}$ at $95^{\circ} \mathrm{C}$, primers annealing for $30 \mathrm{sec}$, elongation $1 \mathrm{~min}$ at $72^{\circ} \mathrm{C}$, the last cycle of the synthesis- $10 \mathrm{~min}$ at $72^{\circ} \mathrm{C}$. Annealing temperature for all primers RM24545, RM 1377, RM 231 RM 569 was $55^{\circ} \mathrm{C}$. For the electrophoretic separation of PCR products, $8 \%$ polyacrylamide gel was used and based on $1 \times$ Tris-borate buffer $(0.09$, M Tris, $0.09 \mathrm{M}$ boric acid, 2 mM EDTA, $\mathrm{pH}=8.2$ ), electrophoresis was performed at the voltage of $200 \mathrm{~V}$. Visualization was performed on the Vilber Lourmat transilluminator after staining the gels with Ethidium Bromide (EtBr).

\section{Results}

\section{The Laboratory Screening of Rice Varieties for Cold Tolerance}

In the controlled conditions, 29 rice varieties were screened for cold tolerance and cold sensitivity. Russian grade Kuban 3 was used as the cold-tolerant standard. The criterion for evaluation Germination Energy (GE) is usually the "average time of one seed germination", which shows conventional number of days required for germination of a single seed, rather than the percentage of seeds that germinated in a certain period. If, on the average, the germination energy is, for example, 4.8 days for the first sample and is characterized by many days for the second sample, this indicates that the seeds from the second sample have decreased germination energy, since germination of a single seed requires more time. On the 13-th day of the experiment, seed germination and GE of the studied genotypes were determined at the temperature of $14^{\circ} \mathrm{C}$ (Table 1).

In the reference variant, about $50 \%$ of the studied samples showed high levels of seed germination (>95\%) as early as on the 2-nd day, whereas in the experimental samples, it was observed only on the 5-th day. By the seeds germination ability, the genotypes were divided into 3 groups: Highly cold-tolerant (germination ability of $66-100 \%$ ), medium cold-tolerant (germination ability of 34-66\%) and low cold-tolerant (germination ability of 0-33\%). The cold-tolerant standards Lazurny, Kuban 3 and UzRos 7-13 showed the start of seed germination on the 5-th day, compared to the reference group. South Korean standards of cold tolerance (Jinbubyeo, Odaebyeo) and Kazakhstan's regioned varieties, which belong to subspecies japonica (except for KazNIIR 5), such as Opytny, Altynai, Aru, Marzhan, Akdala, Madina, Bakanas and Aral 202, are classified as medium cold-tolerant. Rice varieties of the subspecies indica Tybonet, Charm, Izumrud, Ko 293 IRRI, Pak-Li and Snezhinka are classified as cold sensitive.

In our experiment, three repetitions were combined into one, then 20-30 seedlings were taken by the method of the average sample and the length of their coleoptile was measured, after which the general average value of this body was calculated for the analyzed samples. In this study, when the length of the coleoptiles of the seedlings was measured, a distinct pattern was observed: In case of a short time of germination power, the length of the coleoptile increases. For example, if varieties Lazurny, UzRos 7-13 and Kuban 3 in terms of GP were characterized by the short time, in terms of the length of the coleoptile, they were characterized by the greatest value $(0.67$ to $0.76 \mathrm{~cm})$ (Fig. 1).

\section{Creation of Domestic Cold-Tolerant Hybrids with Involvement of Foreign and Domestic Cold- Tolerant Rice Varieties Using the Method of Traditional Breeding}

In 2015, we sowed the genotypes selected for hybridization in three periods with the interval of 10 days to align the time of emergence and flowering and grown in vegetation pots in a greenhouse of IRRP. Hybridization of cold-tolerant foreign rice varieties with the varieties of Kazakhstan breeding was performed with the help of a pneumatic sterilizer and the TWELL method of pollination. The use of this method of pollination significantly increases the set of hybrid seeds in greenhouse conditions. In the work, we also used the South Korean cold tolerance standards-Odaebyeo and Jinbubyeo, which are tolerant to low temperatures and feature high growth rates in the phases of sprouting and tillering as a male paternal form. As a result of hybridization, the total of 1,771 sets of 30 combinations were pollinated and 264 fertile hydride caryopsides were obtained (the set is 16\%) (Table 2).

The abnormally hot weather contributed to a decreased set of hybrid seeds, since the temperature in the greenhouses reached $40-45^{\circ} \mathrm{C}$, which resulted in rapid drying of stigmas of the set. With that, the set of caryopsides was 1 to $45 \%$. It is known that the optimum temperature for setting hybrid caryopsides is 24 to $28^{\circ} \mathrm{C}$; the maximum temperature is $36^{\circ} \mathrm{C}$. More hybrid seeds were set in combinations: Jinbubyeo/Avantgarde-25\%; Altynay/Marzhan-27\%; $\quad$ Kuban $\quad 3 / L i m a n-30 \%$; Opytny/Madina-31\%; $\quad$ Mustakillik/Avantgarde-40\%; Opytny/Marzhan- $45 \%$.

In 2016, the obtained hybrid caryopsides were sown in a greenhouse for reproduction of the first generation hybrids. After ripening, each hybrid combination was harvested separately and sterility of obtained $F_{1}$ hybrids was determined (Table 3). 
Table 1. Rice varieties included into the state register of breeding achievements of kazakhstan and the foreign varieties used in screening for cold tolerance during seeds germination stage

\begin{tabular}{|c|c|c|c|c|c|c|}
\hline \multirow[b]{2}{*}{ Genotypes } & \multirow[b]{2}{*}{ Origin } & \multirow[b]{2}{*}{ Subspecies } & \multicolumn{2}{|l|}{ Reference $\left(28^{\circ} \mathrm{C}\right)$} & \multicolumn{2}{|l|}{ Experiment $\left(14^{\circ} \mathrm{C}\right)$} \\
\hline & & & Germination $(\%)$ & GE, day & Germination (\%) & GE, day \\
\hline Avantgarde & Uzbekistan & Jponica & 82.5 & 3.0 & 36.0 & 10.9 \\
\hline Akdala & Kazakhstan & Japonica & 100.0 & 3.7 & 44.0 & 9.4 \\
\hline Altynay & Kazakhstan & Japonica & 95.0 & 2.8 & 40.0 & 8.1 \\
\hline Anait & Russia & Japonica & 90.0 & 2.8 & 52.0 & 9.2 \\
\hline Aral 202 & Kazakhstan & Japonica & 100.0 & 2.7 & 56.0 & 9.8 \\
\hline Aru & Kazakhstan & Japonica & 92.5 & 3.0 & 40.0 & 9.3 \\
\hline Bakanassky & Kazakhstan & Japonica & 100.0 & 2.7 & 52.0 & 9.7 \\
\hline Izumrud & Russia & Indica & 100.0 & 2.2 & 20.0 & 9.0 \\
\hline KazNIIR-5 & Kazakhstan & Japonica & 95.0 & 2.2 & 80.0 & 8.3 \\
\hline Ko 293, IRRI & Philippines & Indica & 100.0 & 3.5 & 20.0 & 10.6 \\
\hline Kuban 3 & Russia & Japonica & 100.0 & 3.5 & 100.0 & 7.4 \\
\hline Kurhcanka & Russia & Japonica & 87.5 & 3.1 & 4.0 & 9.4 \\
\hline Lazurny & Uzbekistan & Indica & 85.0 & 3.1 & 76.0 & 6.4 \\
\hline Lider & Russia & Japonica & 82.5 & 3.2 & 72.0 & 8.6 \\
\hline Liman & Russia & Japonica & 82.5 & 3.3 & 28.0 & 9.6 \\
\hline Madina & Kazakhstan & Japonica & 97.5 & 2.9 & 44.0 & 9.6 \\
\hline Marzhan & Kazakhstan & Japonica & 67.5 & 3.7 & 40.0 & 9.5 \\
\hline Novator & Russia & Japonica & 75.0 & 2.4 & 68.0 & 9.3 \\
\hline Opytnyi & Kazakhstan & Japonica & 87.5 & 3.4 & 36.0 & 8.1 \\
\hline Pak-Li & Kazakhstan & Indica & 80.0 & 2.5 & 28.0 & 10.2 \\
\hline Snezhinka & Russia & Japonica & 100.0 & 2.9 & 28.0 & 9.6 \\
\hline Solnechny & Russia & Japonica & 65.0 & 3.2 & 52.0 & 9.4 \\
\hline Thaibonnet & Italy & Indica & 67.5 & 4.1 & 4.0 & 11.0 \\
\hline UzROS 7-13 & Uzbekistan & Japonica & 85.0 & 3.3 & 68.0 & 6.6 \\
\hline Fisht & Russia & Japonica & 75.0 & 3.9 & 84.0 & 8.29 \\
\hline Sharm & Russia & Japonica & 97.5 & 2.7 & 16.0 & 9.6 \\
\hline Yantar & Russia & Japonica & 95.0 & 2.9 & 36.0 & 8.4 \\
\hline Jinbubyeo & Korea & Japonica & 70.0 & 2.8 & 54.0 & 10.8 \\
\hline Odaebyeo & Korea & Japonica & 75.0 & 2.4 & 49.0 & 10.6 \\
\hline
\end{tabular}

Table 2. Hybridization of perspective coldtolerant rice genotypes in the greenhouse conditions

\begin{tabular}{|c|c|c|c|}
\hline Combination & The number of pollinated sets, PCs & The number of obtained caryopsides, PCs & The seed set $(\%)$ \\
\hline Avantgarde/KazNIIR 5 & 138 & 12 & 8 \\
\hline Avantgarde/Opytny & 101 & 15 & 15 \\
\hline Opytny/Kuban 3 & 75 & 18 & 24 \\
\hline Opytny/Madina & 82 & 26 & 31 \\
\hline Opytny/Aru & 18 & 2 & 11 \\
\hline Opytny /Marzhan & 47 & 21 & 45 \\
\hline Opytny/KazNIIR 5 & 14 & 1 & 7 \\
\hline Kuban 3/Opytny & 116 & 16 & 13 \\
\hline Kuban 3/Liman & 27 & 8 & 30 \\
\hline Kuban 3/KazNIIR 5 & 51 & 2 & 4 \\
\hline Kuban 3/Altynay & 18 & 4 & 22 \\
\hline Kuban 3/Bakanas & 87 & 17 & 19 \\
\hline Altynay /Opytny & 48 & 9 & 18 \\
\hline Altynay/Kuban 3 & 144 & 2 & 1 \\
\hline Altynay/Marzhan & 69 & 19 & 27 \\
\hline Marzhan/Liman & 68 & 2 & 3 \\
\hline Marzhan/Kuban 3 & 62 & 6 & 9 \\
\hline KazNIIR 5/Kuban 3 & 98 & 23 & 23 \\
\hline KazNIIR 5/Opytny & 106 & 6 & 5 \\
\hline KazNIIR 5/Liman & 15 & 2 & 13 \\
\hline KazNIIR 5/Avantgarde & 25 & 1 & 4 \\
\hline Liman/Jinbubyeo & 22 & 2 & 9 \\
\hline Odaebyeo/Madina & 58 & 1 & 2 \\
\hline Lazurny/Opytny & 55 & 1 & 2 \\
\hline Lazurny/Bakanas & 19 & 1 & 5 \\
\hline Lazurny/KazNIIR 5 & 28 & 1 & 3 \\
\hline Jinbabyeo/Avantgarde & 28 & 7 & 25 \\
\hline UzROS 7-13/Marzhan & 63 & 12 & 19 \\
\hline UzROS 7-13/Kuban 3 & 47 & 10 & 21 \\
\hline Mustakillik/Avantgarde & 42 & 17 & 40 \\
\hline Total: & 1771 & 264 & 15 \\
\hline
\end{tabular}


Table 3 . The number of the obtained $\mathrm{F}_{1}$ hybrid caryopsides and their sterility

\begin{tabular}{|c|c|c|}
\hline Combination & Obtained $\mathrm{F}_{1}$ hybrid caryopsides, $\mathrm{PCs}$ & Sterility $(\%)$ \\
\hline Avantgarde/KazNIIR 5 & 638.000 & 40 \\
\hline Avantgarde/Opytny & 910.000 & 29 \\
\hline Opytny/Kuban 3 & 1.214 & 33 \\
\hline Opytny/Madina & 1.430 & 24 \\
\hline Opytny/Aru & 38.000 & 30 \\
\hline Opytny/Marzhan & 2.894 & 20 \\
\hline Opytny/KazNIIR 5 & 56.000 & 16 \\
\hline Kuban 3/Opytny & 448.000 & 14 \\
\hline Kuban 3/Liman & 555.000 & 39 \\
\hline Kuban 3/KazNIIR & 57.000 & 20 \\
\hline Kuban 3/Altynay & 66.000 & 26 \\
\hline Kuban 3/Bakanas & 890.000 & 41 \\
\hline Altynay/Opytny & 1.661 & 32 \\
\hline Altynay/Kuban 3 & 384.000 & 33 \\
\hline Marzhan/Liman & 520.000 & 30 \\
\hline Marzhan/Kuban 3 & 153.000 & 22 \\
\hline KazNIIR 5/Kuban 3 & 954.000 & 16 \\
\hline KazNIIR 5/Opytny & 3.356 & 15 \\
\hline KazNIIR 5/Liman & 79.000 & 40 \\
\hline KazNIIR 5/Altynay & 186.000 & 15 \\
\hline Lyman/Jinbubyeo & 294.000 & 25 \\
\hline Odaebyeo/Madina & 116.000 & 13 \\
\hline Lazurny/KazNIIR 5 & 226.000 & 13 \\
\hline Jinbabyeo/Avantgarde & 296.000 & 25 \\
\hline UzROS 7-13/Marzhan & 663.000 & 13 \\
\hline Mustakillik/Avantgarde & 3.267 & 15 \\
\hline Total: & 21.351 & 25 \\
\hline
\end{tabular}

The highest sterility was shown by combinations Kuban 3/Bakanas (41\%), KazNIIR 5/Altynay (40\%), Avantgarde/KazNIIR 5 (40\%), Kuban 3/Liman (39\%). The lowest sterility was detected in combinations KazNIIR 5/Opytny, KazNIIR 5/3 Kuban, Kuban 3/Opytny, Opytny/KazNIIR 5, KazNIIR 5/Altynay, Odaebyeo/Madina, Lazurny/KazNIIR 5, UzROS 713/Marzhan, Mustakillik/Avantgarde.

\section{Identification of Quantitative Loci of Rice Cold Tolerance}

After hybridization with domestic and foreign varieties, the obtained $F_{1}$ hybrids in various combinations were analyzed with the use of microsatellite markers that are closely related to the cold tolerance trait RM 24545, RM 1377, RM 231, RM 569 (Suh et al., 2010). The nucleotide sequence of primer pairs of cold tolerance markers is shown in Table 4.

The Quantitative loci of cold tolerance (QTLs): qPSST-3, qPSST-7 and qPSST-9) in the studies genetic plasma of rice were identified by PCR analysis. For performing the DNA analysis, PCR and electrophoresis parameters were optimized at the initial stage. PCR products were separated in an $8 \%$ polyacrylamide gel. The positive reference were coldtolerant standards of rice: Varieties Kuban 3 and
UzROS 7-13. The microsatellite profiles of studied samples in the studied DNA loci are shown in Fig. 2-5.

As Fig. 4 shows, the microsatellite marker RM24545 did not reveal polymorphism among the studied samples of rice, DNA fragments of all varieties and hybrids were of identical size. All parent varieties and their $\mathrm{F}_{1}$ hybrids, including cold-tolerant reference varieties Kuban 3 and UzROS 7-13, had the same allele. It is expressed in the electrophoretogram by the presence of PCR fragments located at the same positions with the size of $152 \mathrm{bps}$.

In visualization of the results in an $8 \%$ polyacrylamide gel, the RM1377 microsatellite marker revealed two alleles in the studied samples: The allele of "cold tolerance" is inherent in No. 1-5, 7-31, 33-37; the allele of "cold sensitivity" is inherent in the coldsensitive grade Lyman (No. 6 sample) and in hybrid Lyman/Jinbubyeo (No. 32). The electrophoretogram clearly expresses amplified fragments of these samples, which are different in the size from other samples. For example, the cold-sensitive grade Lyman (sample No. 6) and $F_{1}$ hybrid Lyman/Jinbubyeo amplified a DNA fragment with the size of about 200 bps and in the rest of the studied samples, the DNA fragment had the length of about 152 bps.

Thus, this marker showed polymorphism and allowed ranking samples of rice that are contrasting by the studied trait. 
Table 4. Sequence of primer pairs of microsatellite markers (Gramene. Microsad, n. d.)

\begin{tabular}{|c|c|c|c|c|}
\hline Primer & Nucleotide sequence & Product size & Annealing $\mathrm{t}\left({ }^{\circ} \mathrm{C}\right)$ & Localization in the chromosome \\
\hline RM 24545 & $\begin{array}{l}\text { F-ACAGCACAGCACCCGGAAGG } \\
\text { R-GAGCAACAGGAAGGCGATAAGC }\end{array}$ & 152 bps & 55 & 9 \\
\hline RM 1377 & $\begin{array}{l}\text { F-ATTAGATACATCAGCGGGGG } \\
\text { R-GCTGCTGTACGATGTGATCC }\end{array}$ & $181 \mathrm{bps}$ & 55 & 7 \\
\hline RM 231 & $\begin{array}{l}\text { F-CCAGATTATTTCCTGAGGTC } \\
\text { R-CACTTGCATAGTTCTGCATTG }\end{array}$ & 182 bps & 55 & 3 \\
\hline RM 569 & $\begin{array}{l}\text { F-GACATTCTCGCTTGCTCCTC } \\
\text { R-TGTCCCСТCTAAAACCCTCC }\end{array}$ & $175 \mathrm{bps}$ & 55 & 3 \\
\hline
\end{tabular}

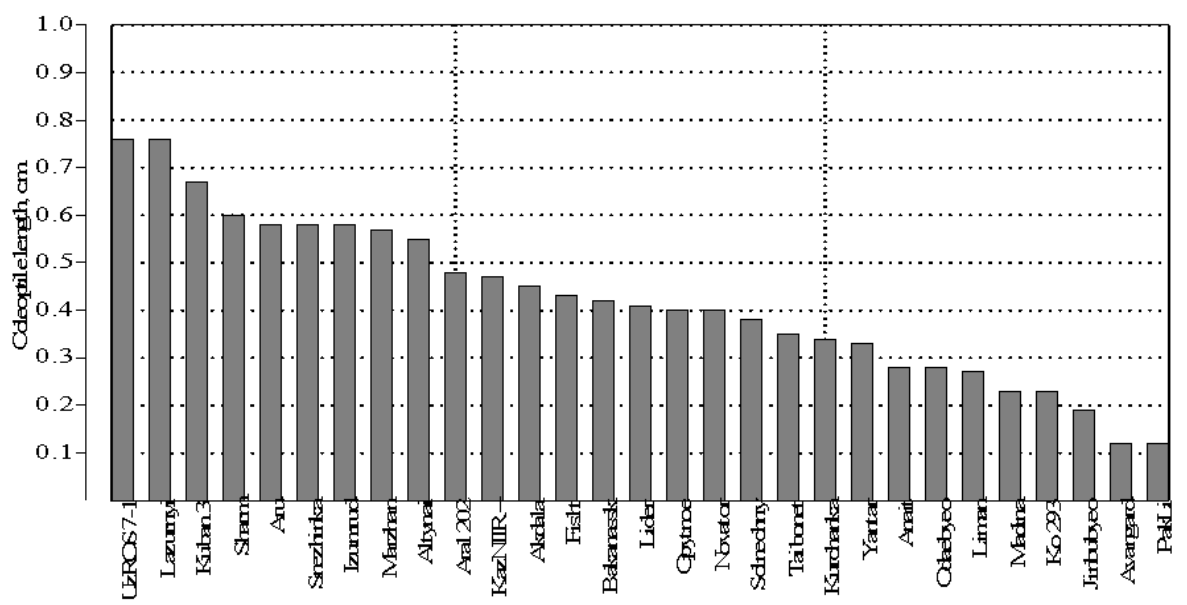

Fig. 1. The length of coleoptile $(\mathrm{cm})$ in samples at the temperature of $14^{\circ} \mathrm{C}$

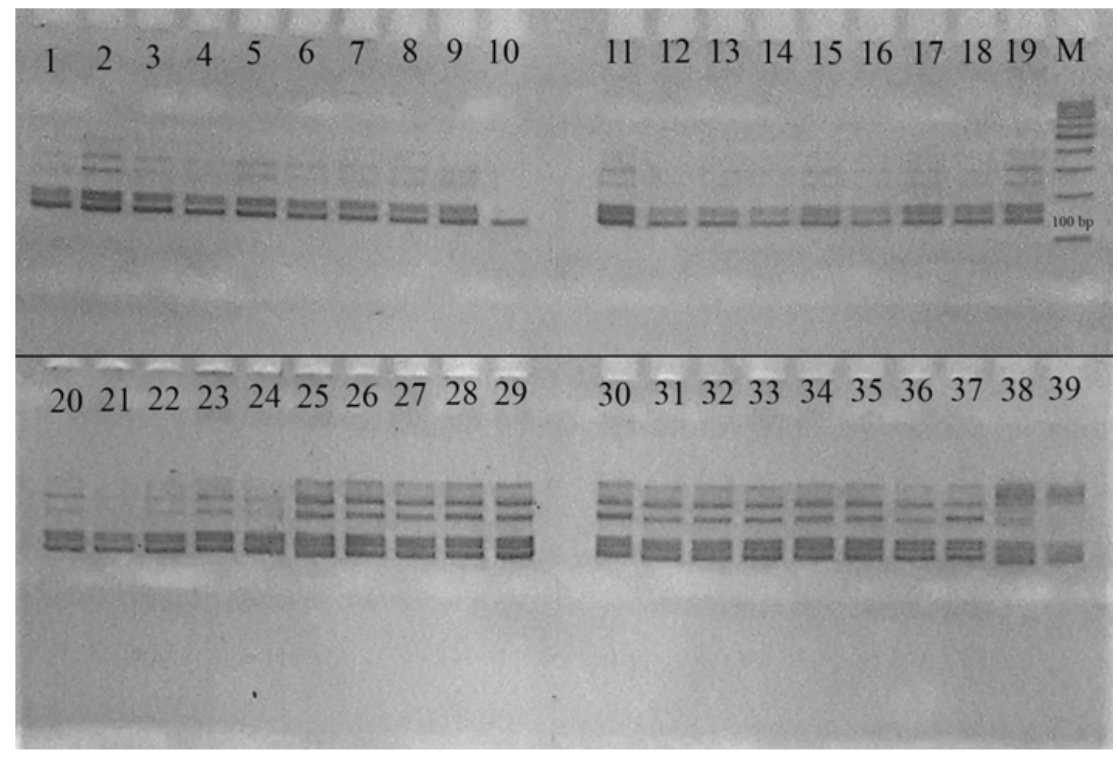

Fig. 2. Allelomorphic migration in the RM24545 microsatellite locus in rice samples Note: 1-Avantgarde, 2-Opytny, 3-Marzhan, 4-

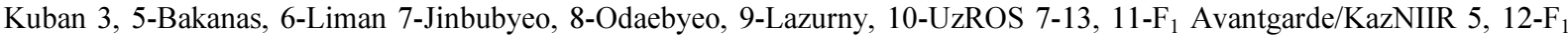

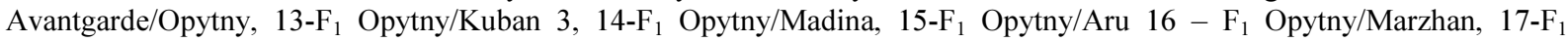

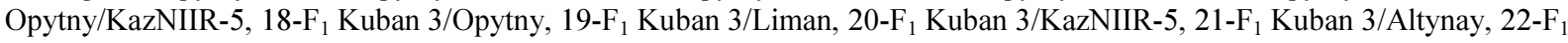

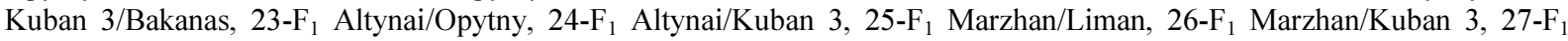

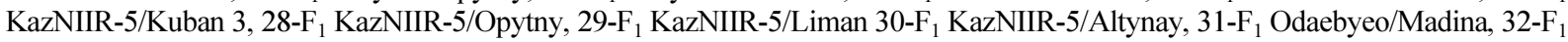

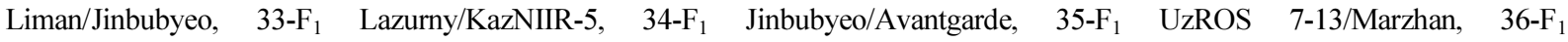
Mustakillik/Avantgarde, 37-Aru, 38- $\mathrm{F}_{1}$ FL 478/Todorokiwase, 39-F 1 FL 478/Reiziq 


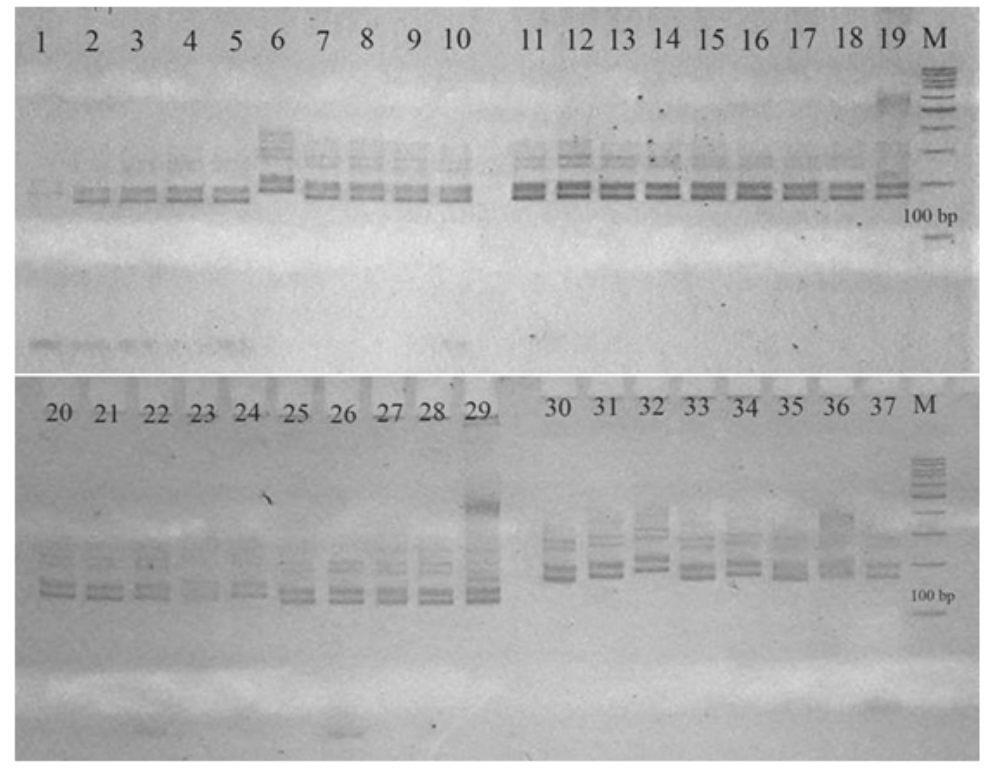

Fig. 3. Allelomorphic migration in the RM1377 microsatellite locus in rice samples Note: 1-Avantgarde, 2-Opytny, 3-Marzhan, 4-

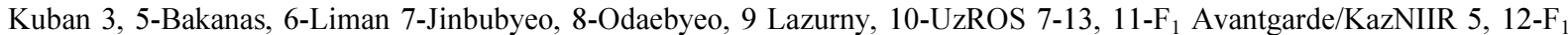

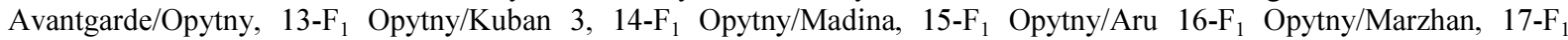

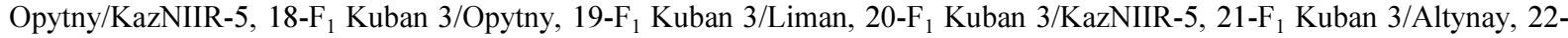

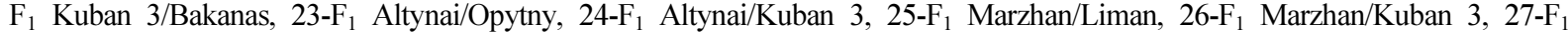

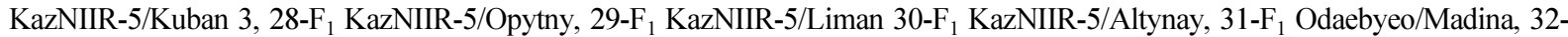

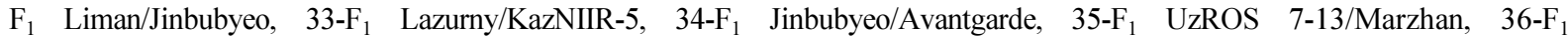
Mustakillik/Avantgarde, 37-Aru.

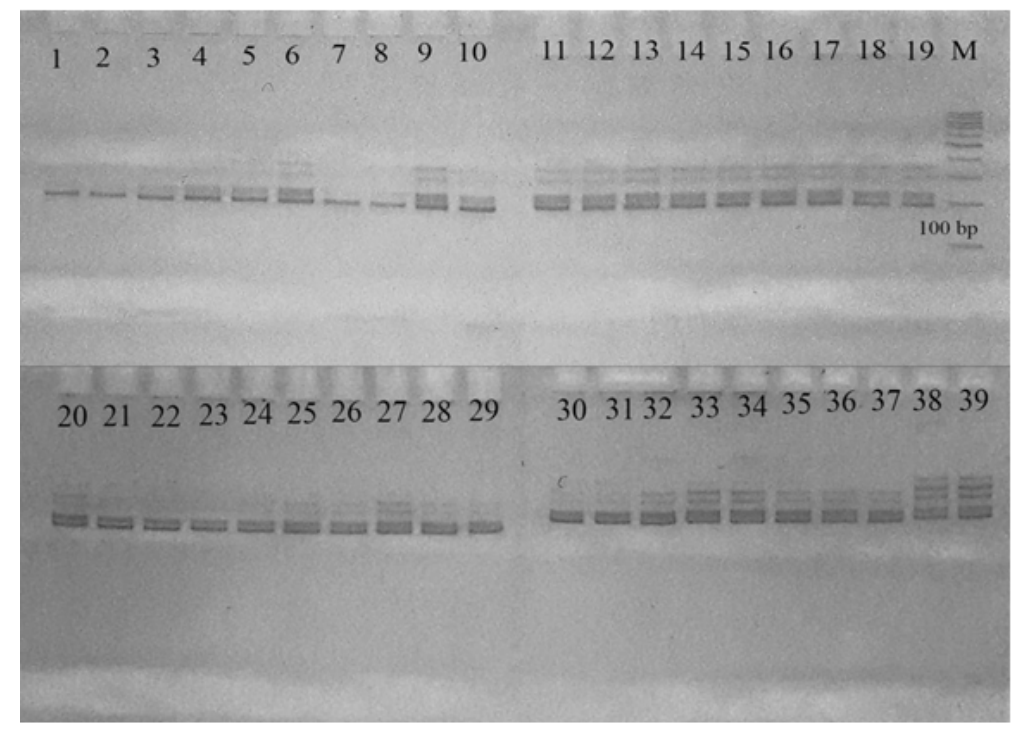

Fig. 4. Allelomorphic migration in the RM231 microsatellite locus in rice samples Note: 1-Avantgarde, 2-Opytny, 3-Marzhan, 4-Kuban 3,

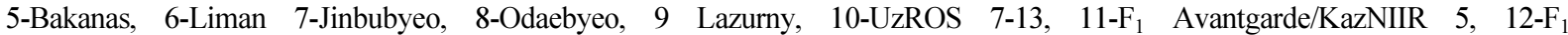

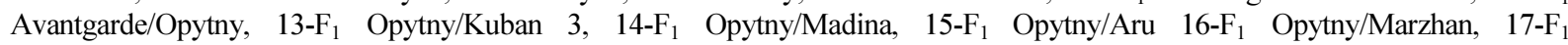

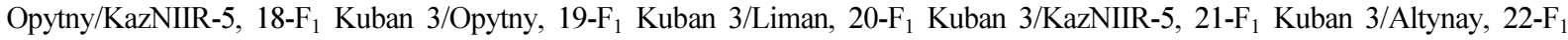

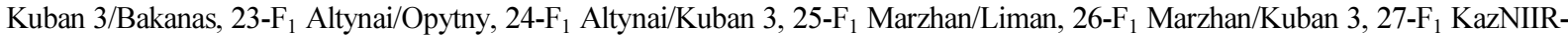

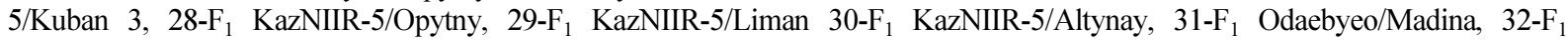

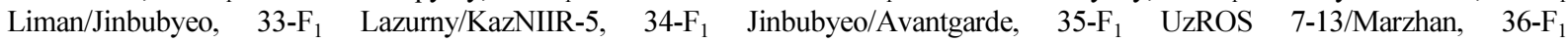
Mustakillik/Avantgarde, 37-Aru, 38- $\mathrm{F}_{1}$ FL 478/Todorokiwase, 39-F FL 478/Reiziq 


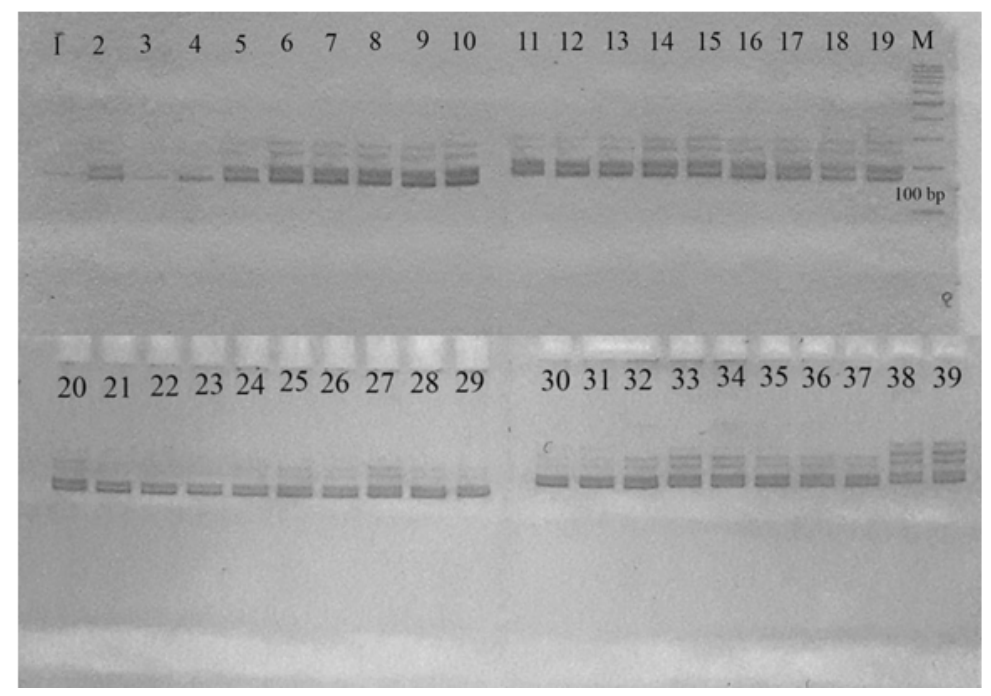

Fig. 5. Allelomorphic migration in the RM569 microsatellite locus in rice samples Note: 1-Avantgarde, 2-Opytny, 3-Marzhan, 4-Kuban 3,

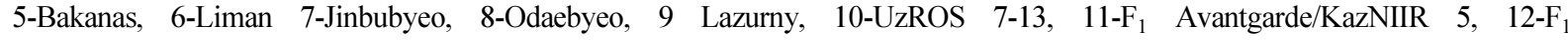

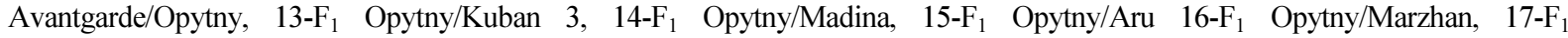

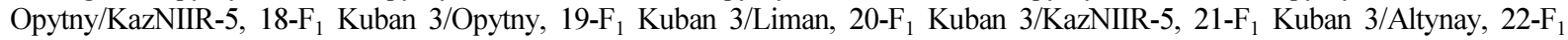

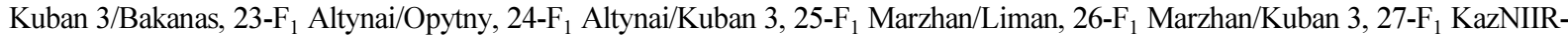

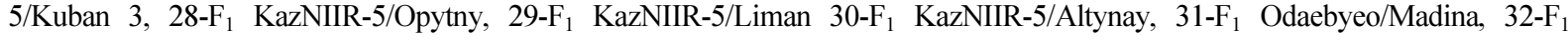

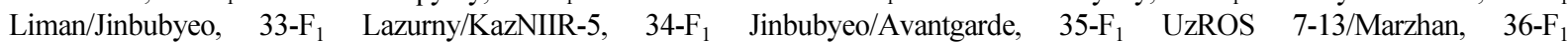

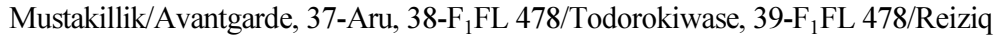

Visualization of the results in a $8 \%$ polyacrylamide gel showed that in the initial parental varieties (samples No. 1 to 10), marker RM231 amplified only one fragment with the size of about $180 \mathrm{bps}$, while in $\mathrm{F}_{1}$ hybrids (samples No. 11 to 37 ) primers of this marker amplified two fragments with the size of about 180 and $210 \mathrm{bps}$, which indicates the possibility of hybrid purity of $F_{1}$ generations.

Marker RM569 for all studied genotypes turned out to be monomorphic. In DNA amplification by this marker, only one fragment was obtained with the length of about $175 \mathrm{bps}$ for both the initial parental forms and their hybrids.

\section{Discussion}

The obtained preliminary data indicate that the studied samples of rice are different by the GP. In the reference samples at the temperature of $28^{\circ} \mathrm{C}$, this indicator ranged between 2.2 and 4.1 days, regardless of the systematic and geographical origin of the varieties. In the experimental samples, at the temperature of $14^{\circ} \mathrm{C}$, the least number of days in terms of germination rate was characteristic of the variety bredat Uzbek $R \& R$ Institute of Rice (Lazurny, UzROS 7-13) and AllRussian R\&R Institute of Rice (Kuban 3). On the average, this indicator for grades Lazurny, UzROS 7-13 and Kuban 3 was 6 to 7 days, which provides the basis for including them into breeding work for creating a cold-tolerant source material.

By the examined trait, the studied samples were divided into 4 groups. The first group includes the genotypes that have the lowest indices of GE, germination of seeds in which requires the least number of days (6.4 to 7.4). The second group, which is dramatically different from the first one, includes the genotypes characterized by the average GE (8.1 to 8.6 days). Groups III and IV include genotypes with high levels of GE: 8.8 to 9.8 and 10.2 to 11.0 days, respectively (Fig. 6).

It has been found that 14 out of 29 studied genotypes may be allocated to the third group, which allows considering them as medium cold-tolerant.

According to (da Cruz and Milach, 2004), by the change of the length of the coleoptile alone, it is possible to identify a clear difference between cold sensitive and cold-tolerant genotypes (Cruz et al., 2006).

As a result of screening 29 genotypes, it has been found that the genotypes differ in the length of coleoptiles and by this trait, they may be divided into three groups:

- Short coleoptiles-the average length is 0.12 to $0.33 \mathrm{~mm}$

- Medium coleoptiles-the average length is 0.34 to $0.55 \mathrm{~mm}$

- Long coleoptiles-the average length is $0.56 \mathrm{~cm}$ and more (Fig. 7) 


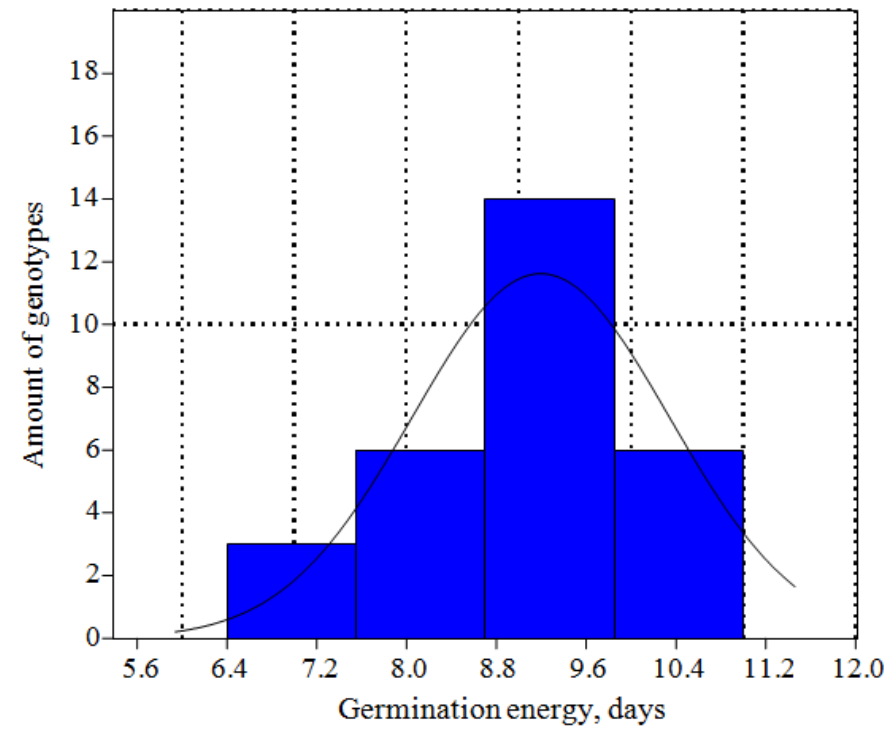

Fig. 6. Ranking rice samples by GP in terms of cold tolerance

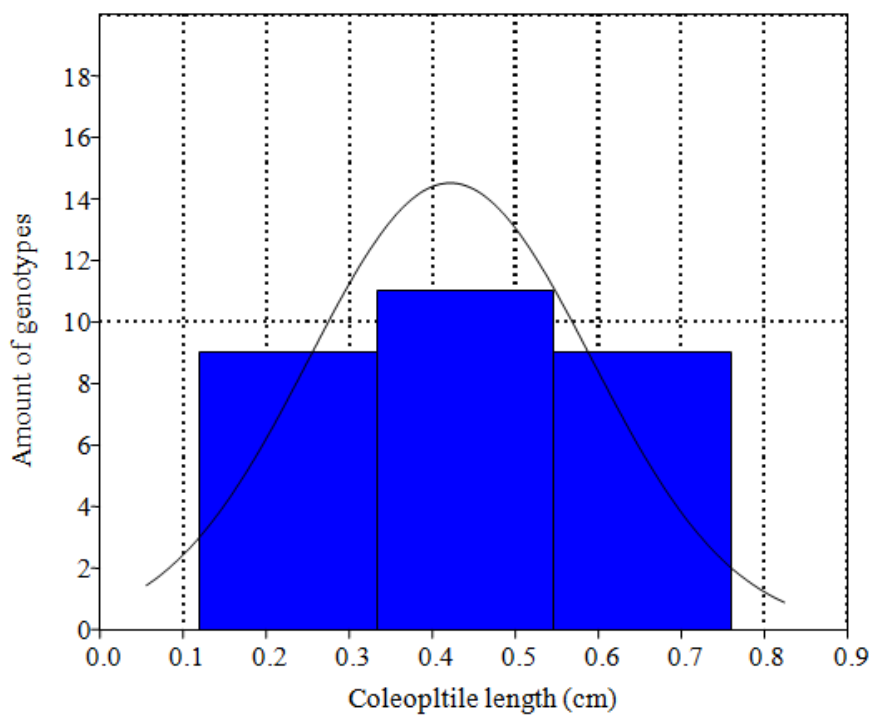

Fig. 7. Ranking rice sample by the length of coleoptiles

The experimental data allow drawing a conclusion that with an increased germination power, in most genotypes the coleoptile growth rate reduces. The correlation indicates an inverse relation between these traits $(r=-0.60)$. The detected regularities indicate inappropriateness of including into breeding scheme in terms of cold tolerance the genotypes that belong to subspecies indica, since varieties Thai bonnet, Charm, Emerald, Ko 293 IRRI, Pak Lee and Snezhinka that belong to subspecies indica turned out to be coldsensitive. It is known that subspecies indica is mostly widespread in the subtropical regions and, predominantly in the tropics. Therefore, varieties of subspecies indica are not characterized by intensive growth in the early stages due to higher adaptation to the root-to-seed culture and in case of direct sowing with complete flooding, form very sparse seedlings and often die completely (Podolskikh and Baybosynova, 2016). In our studies, the only exception was the coldtolerant variety-Lazurny bred at the Uzbek R\&R Institute of rice, which also belongs to the indica subspecies. By the results of screening, of all studied samples, the most cold-tolerant in the early stage of growth were rice varieties Kuban 3 (Russian standard of cold tolerance), UzROS 7-13 and Lazurny (Zhanbyrbayev et al., 2016). 
Rice is a thermo-sensitive crop and its productivity decreases sharply at low temperatures. The period of limited duration with the temperatures that are favorable for rice vegetation in the Northern zone of the ricegrowing regions of Kazakhstan makes rice producers of the Republic sow it earlier at the temperature of 14$16^{\circ} \mathrm{C}$. Creating cold-tolerant varieties is especially important for the Northern rice-producing regions of the Republic, as up to $20-30 \%$ of the seedlings die in the spring of anomalous years due to cold stress. One of the most effective ways to avoid the effect of low temperatures is creating cold-tolerant rice genotypes (Lou et al., 2007). The weather conditions in the Almaty region do not allow complete ripening of cold-tolerant varieties bred at the Uzbek $R \& R$ Institute of Rice (UzRos 7-13 and Lazurny), the vegetation period of which is 135-140 days. Therefore, in creating coldtolerant hybrids, the promising cold-tolerant varieties selected according to the results of laboratory screening were used as female parent form and the early-ripening and medium-ripening varieties zoned in Almaty and Kyzylorda regions were used as the male parent form.

When the cold-tolerant variety of rice bred at the Uzbek R\&R Institute of Rice-Lazurny- was used as female parent form, the set of hybrid caryopsides was very low, compared to other varieties, as this variety belongs to the subspecies indicakato (a variety of var. gilanica Gust), in combinations japonicaxindica incompatibility is more pronounced, which results in a weaker fertilization process. It is known that in crossing varieties of Indian and Japanese subspecies, selections should be started with the third generation, as earlier generations have higher sterility. After replanting for several years, natural selection of fertile forms occurs in them, which confirms the obtained data.

In greenhouse conditions, IBBR with hybridization of cold-tolerant foreign rice genotypes with domestic rice varieties in abnormally hot weather conditions, 264 hybrid caryopsides were obtained from 30 combinations of crossbreeding. Subsequent reproduction of $F_{0}$ generation in 2016 allowed obtaining 21,351 pcs of $F_{1}$ hybrid caryopsides from 26 combinations, which is of interest as a promising source material for breeding in terms of rice cold tolerance.

Modern technologies based on using systems based on DNA markers (RAPD, SSR, ISSR) have been successfully used for molecular-genetic characterization of hybrids and their parental forms. The most reliable and reproducible are SSR markers based on polymorphism of the length of the short repeats distributed throughout the genome. Compared to other methods, the use of SSR markers ensures high reliability and reproducibility. The co-dominant nature of these markers allows to distinguish homo-and heterozygous plants, which is very important for early identification of hybrids and considerably saves time in creating a new selection of important original forms (Brown et al., 1996).
From the obtained data, DNA polymorphism of the initial parent varieties and rice hybrids in microsatellite loci was detected, which are closely related to the quantitative loci of cold rice tolerance (qPSST-3, qPSST-7 and qPSST-9) located in chromosomes 3, 7 and 9, respectively. As a result of the PCR analysis, it has been revealed that out of 4 studied markers (RM 24545, RM 569, RM 231, RM 1377) only one marker RM 1377 turned out the most informative. This marker RM1377 allowed to detect two alleles in the studied samples: "Cold tolerance" and "cold sensitivity".

\section{Conclusion}

Thus, by the results of screening, the most coldtolerant species were selected in the early phase of rice growth, such as Kuban 3, UzROS 7-13 and Lazurny. The chosen promising varieties were used as the female parent form for creating cold-tolerant hybrids. By the DNA analysis of the three microsatellite markers (RM24545, RM569, RM231, RM1377) related to cold tolerance QTLs, no allelic diversity was found in the studied samples of rice. Only marker RM 1377 was most informative, compared to others. In general, it should be noted that screening tests of IRRP rice genetic plasma for cold tolerance helped to identify donors of useful agronomic traits, which are extremely important for developing promising pre-selection resources.

\section{Acknowledgement}

We thank university financial departments for support our study.

\section{Author's Contributions}

Yeldos Almabekovich Zhanbyrbayev: Provided leadership and coordinated the implementation of research work, analyzed and interpreted the study findings, drew conclusions.

Aiman Bokenovna Rysbekova: Involved in all experiments, obtained data analyses and contributed to the scientific writing of the manuscript.

Bakdaulet Naubaevich Usenbekov: Involved in all experiments, obtained data analyses and contributed to the scientific writing of the manuscript.

Dauren Tabiyltaevish Kazkeyev: Involved in all experiments, obtained data analyses and contributed to the scientific writing of the manuscript.

Batyrbek Ashirimbetovich Sarsenbayev: Conducted research, compiled the literary review, analyzed and interpreted the results.

Grigoriy Leonidovich Zelensky: Conducted research, compiled the literary review, analyzed and interpreted the results. 


\section{Ethics}

This article is original and contains unpublished material. The corresponding author confirms that all of the other authors have read and approved the manuscript and no ethical issues involved.

\section{References}

Brown, S.M., A.K. Szewc-McFadden and S. Kresovich, 1996. Development and application of Simple Sequence Repeat (SSR) loci for plant genome analysis. New York, CRC.

da Cruz, R.P. and S.C.K. Milach, 2004. Cold tolerance at the germination stage of rice: Methods of evaluation and characterization of enotypes. Sci. Agric. (Piracicaba, Braz.), 61: 1-8.

Cruz, R.P., S.C.K. Milach and L.C. Federizzi, 2006. Inheritance of rice cold tolerance at the germination stage. Genetics Molecular Biol., 29: 314-320. DOI: $10.1590 / \mathrm{S} 1415-47572006000200020$

Gramene. Microsad. (n. d.). Date View April 30, 2017

Kovalenko, V.I. and V.P. Dudenko, 1974. Kultura Risa v Kazahstane [The Rice Culture in Kazakhstan]. 1st Edn., Kainar, Alma-Ata, pp: 176.

Kostylev, P.I., V.I. Stepovoy and A.A. Parfenyuk, 2004. Severnyi Ris [Northern Rice]. 1st Edn., ZAO "Kniga", Rostov-na-Donu, pp: 576.

Los, G.D., 2007. Metodika gibridizatsii risa [Methods of rice hybridization]. Rice Growing, 10: 42-51.

Lou, Q., L. Chen, Z. Sun, Y. Xing and J. Li et al., 2007. A major QTL associated with cold tolerance at seedling stage in rice (Oryza sativa L.). Euphytica, 158: 87-94.
Murray, M.G. and W.F. Thompson, 1980. Rapid isolation of high molecular weight DNA. Nucleic Acids Res., 8: 4321-4325.

Podolskikh, A.N. and S.M. Baybosynova, 2016. Intensivnost prorastaniya kazahstanskih linii risa podvida indika. [Intensity of germination of the Kazakh lines of the indica rice subspecies]. Rice Cultivation, 1-2: 38-41.

Saito, K., Y. Hayano-Saito, W. Maruyama-Funatsuki Y. Sato and A. Kato, 2004. Physical mapping and putative candidate gene identification of a quantitative trait locus Ctb1 for cold tolerance at the booting stage of rice. Theor. Applied Genet., 109: 515-522.

Skazhenik, M.A., N.V. Vorobyov and O.A. Doseeva, 2009. Metodi Fiziologicheskih Issledovanii v Risovodstve. [Methods for Physiological Studies in Rice Breeding]. 1st Edn., All-Russian R\&R Institute of Rice, Krasnodar, pp: 23.

Suh, J.P., J.U. Jeung, J.I. Lee, Y.H. Choi and J.D. Yea et al., 2010. Identification and analysis of QTLs controlling cold tolerance at the reproductive stage and validation of effective QTLs in cold-tolerance genotypes of rice (Oryza sativa L.). Theor. Applied Genet., 120: 985-995. DOI: 10.1007/s00122-009-1226-8

Takeuchi, Y., H. Hayasaka, B. Chiba, I. Tanaka and T. Shimano et al., 2001. Mapping quantitative trait loci controlling cool-temperature tolerance at booting stage in temperate japonica rice. Breed. Sci., 51: 191-197. DOI: 10.1270/jsbbs.51.191

Zhanbyrbayev, Y.A., A.B. Rysbekova, B.N. Usenbekov, D.T. Kazkeev and I.A. Sartbayeva et al., 2016. Screening rice (Oryza sativa L.) genetic resources for cold tolerance at the germination stage. Biosciences Biotechnol. Res. Asia, 13: 1969-1973 